\title{
STIMULATING TEACHING AND LEARNING INNOVATIONS TO ENHANCE HIGHER EDUCATION QUALITY
}

\author{
Ines Dužević ${ }^{1}$, Tomislav Baković ${ }^{2}$ Mia Delićc ${ }^{3}$
}

UDC / UDK: 001.895:378:658.56(497.5)

JEL classification / JEL klasifikacija: I23, O

DOI: https://doi.org/10.22598/pi-be/2019.13.1.13

Original scientific paper / Izvorni znanstveni rad

Received / Primljeno: December 10, 2018 / 10. prosinca 2018.

Accepted for publishing / Prihvaćeno za tisak: March 15, 2019 / 15. ožujka

2019.

\section{Summary}

The purpose of this paper is to examine the innovative practices that can be used as a tool for quality enhancement in higher education. More specifically, the paper seeks to examine how specific innovation contributes to the achievement of strategic goals and to reveal the most influencing practices for higher education institutions. The study included two phases: a survey and structured interviews with the management of the higher education institutions. A survey was conducted to determine the level of innovativeness and strategic planning in Croatian higher education institutions. In total, 135 managers' replies were collected. Second phase included structured interviews with managers from 11 higher education institutions. The research revealed that, although majority of Croatian higher education institutions (HEIs) implemented strategy and plans for enhancing teaching quality, it doesn't fulfil their aim to motivate students and to enhance their teaching and learning practices. This paper integrates different approaches in analysis of teaching and learning quality. It combines strategic and innovation management with quality management practices and provides comprehensive framework for investigating teaching and learning (T\&L) quality. The study draws attention to the importance of innovative practices as a tool for quality enhancement in

\footnotetext{
${ }^{1}$ Ines Dužević, Ph.D., Assistant Professor, Faculty of Economics \& Business, University of Zagreb, Department of Trade and International Business, Zagreb, Croatia, E-mail: iduzevic@efzg.hr*corresponding author

2 Tomislav Baković, Ph.D., Associate professor; Faculty of Economics \& Business, University of Zagreb, Department of Trade and International Business, Zagreb, Croatia, E-mail: tbakovic@efzg.hr

${ }^{3}$ Mia Delić, Ph,D., Postdoctoral researcher; Faculty of Economics \& Business, University of Zagreb, Department of Trade and International Business, Zagreb, Croatia, E-mail: mdelic@efzg.hr
} 
higher education and suggests a set of guidelines for HEI's management to enhance teaching and learning quality.

Key words: Service Quality, Innovation, Quality enhancement, Higher Education, Croatia.

\section{INTRODUCTION}

The dynamic changes in higher education context call for the shift from quality assurance to quality enhancement. Rapid expansion of universities and intense competition, combined with a falling birth-rate are forcing universities to focus on continuous improvement using total quality management (TQM) principles (Hsu, Wang, Cheng \& Chen, 2016). To enhance quality and competitiveness, higher education institutions (HEIs) should focus on their students. Modern education systems are based on student-centred learning that include transformation of education processes towards research activities and adaptation of experience based teaching methods (Klyap \& Klyap, 2016). Since culture is rapidly changing, we cannot expect that students remain same (Lane, Hunt \& Farris, 2011). Accordingly, they must be seen as active participants of the education process, and not as passive recipients or customers (Bovill, Cook-Sather, Felten, Millard \& Moore-Cherry, 2016). Efficient learning-centred teaching is designed to promote student learning. Practices that encourage student engagement and formative assessment of learning outcomes will lead to higher student achievements (Dochy, Berghmans, Kyndt \& Baeten, 2011; Mostrom \& Blumberg, 2012; Nordstrom \& Korpelainen, 2011).

Students need to learn more in less time, and quality has become increasingly important in higher education (Duque, 2014). There are many parallels between quality thinking and recent developments in higher education teaching methodology (Longstrand, Cronemyr \& Poksinska, 2015). However, there are many different conceptions and approaches to analysing quality from student-centred viewpoint (Hsu et al., 2016; Langstrand, Cronemyr \& Poksinska, 2015; Pérez Rave \& Muñoz Giraldo, 2016). Student satisfaction surveys are often used, but these tend to be crude and ad hoc (Hsu et al., 2016). This study aims to implement deeper approach to define how innovative practices at the managerial level could be used for achieving better student results and increase their satisfaction.

The vast number of studies highlighted the need for more research in optimizing organizational design to support innovations (Barnard \& Van der Merve, 2016; Chen, Chen \& Padró, 2017, 2017; Smith, 2012). Klyap and Klyap (2016) suggested further research to analyse most effective innovative methods that can be used for training students. The study from Poland by Wiśniewska and Grudowski (2016) promoted more research to propose the future directions of academic staff development, as a key element of the HEI's development. Moreover, most of the previous studies restricted the reach of quality management and innovations to the teaching level (Chen et al., 2014; Iwakami Beltrão \& Barçante, 2016; Langstrand et al., 2015). Manatos, Sarrico \& Rosa (2017) emphasised the need for integration of quality management practices in the broader 
management system. They suggested that quality management practices should be an integral part of the development of the HEI and its strategic plan. Since strategic planning and innovativeness are closely related to the quality management principles of leadership and continuous improvement, they cannot be analysed separately. Gray and Radloff (2010) also stimulated further research into the potential for teaching and learning (T\&L) plans to address major themes and issues. As Hofmeyer, Sheingold, Klopper \& Warland (2015:188) correctly argued:

"There is a gap between subcultures that value leadership in learning and teaching, mentoring colleagues and students, and celebrating everyday teaching achievements [...] and cultures that fail to clarify metrics or offer clear incentives and rewards. It is necessary to bridge this gap by fostering urgent cultural change that supports academics to build their leadership in teaching to provide quality experiences for students, and contribute to societal expectations of higher education."

This study aims to contribute to a better understanding of managerial practices that promote innovativeness in T\&L.

This paragraph provides an overview of Croatian higher education system in order to explain the context of the study. It is part of European system with strong support towards standardization of quality assurance based on the European standards and guidelines for quality assurance in higher education (ESG). Thus, emphasis is placed on internal evaluation of quality and little is said about external evaluation of quality (Hrničer \& Madzik, 2017). It has been undergoing a transformation in the last two decades. Bologna Declaration was signed in 2001 and since 2005 all study programs in Croatian higher education area are adopted to the Bologna principles. Development of the Croatian Qualification Framework began in 2006 and has been fully implemented since 2013. State Matura for high school graduated started in the academic year 2009/2010, and the system for applications and enrolment to the higher education changed. Furthermore, in 2009 The Act on Quality Assurance in Science and Higher Education was passed which was the prerequisite to implement the evaluations of HEIs. Since then, all Croatian HEIs have been evaluated according to ESG and other criteria set by the Agency for Science and Higher Education. A need for continuous adaptation to new requirements set by the government and strong competition in the higher education, especially since European Union accession, encouraged Croatian HEIs to shift from quality assurance towards quality enhancement. However, the HEIs are still finding it difficult to retain and engage students. According to the Kashif, Ramayah and Sarifuddin (2016) this may be due to the absence of a 'customer-centric' approach resulting in high student dropout and failure rates.

This paper analyses innovative practices in T\&L and their relationship with the quality enhancement activities implemented by the management of the HEI. To define quality enhancement strategies in the area of T\&L, we set three research goals: (1) to examine functioning of the institutional framework for T\&L enhancement; (2) to explore importance and inclusion of T\&L issues in HEI's strategic plans; and (3) to define practices and procedures for quality enhancement in T\&L. Combining quantitative and qualitative research methods, this study provides comprehensive insight into possibilities 
for quality enhancement in T\&L that may help HEI's management in dealing with one of the most challenging task, i.e. engaging and motivating their students.

\section{LITERATURE REVIEW}

There are many different conceptions of service quality in higher education resulting in difficulties in measuring service quality (Chen et al., 2017; Lazibat, Baković \& Dužević, 2014; Mikulić, Dužević \& Baković., 2015; Owlia \& Aspinwall, 1996). However, there is a consensus about the importance of student-centred approaches as essential aspect for the survival and success of HEIs (Pérez Rave \& Muñoz Giraldo, 2016). HEIs may use different quality management conceptions when trying to include quality principles in their strategies, such as: ISO 9001 standard (Chen et al., 2017), European Foundation for Quality Management (EFQM) model (Campatelli, Citti and Maneghin, 2011; Sadeh \& Garkaz, 2015), Six Sigma (Campatelli et al., 2011). However, it is difficult to translate quality management principles to a higher education setting. Rosa, Sarrico \& Amaral, (2012) noted following obstacles: the strong academic culture that opposes to changes, insufficient leadership commitment, large time demands for individual training on quality, absence of effective communication channels, difficulty of measuring results, increased levels of bureaucracy, problematic terminology, the view of TQM as just another management fad, and multiple types of 'customers' with different requirements. The most significant success factors for quality management implementation in higher education include: leadership and top management commitment, student focus, involvement of employees and other stakeholders, teamwork and effective communication, process management, program design, measurement and evaluation, and organizational culture (Bayraktar, Tatoglu \& Zaim, 2008; Jaca \& Psomas, 2015; Sadeh \& Garkaz, 2015). Recent studies suggested that implementation of quality management practices in higher education should be integral part of the HEI's development and of their strategic plan (Chen et al., 2017; Manatos et al., 2017; Rosa et al., 2012; Sadeh \& Garkaz, 2015). Accordingly, this study aims to find out if HEIs have implemented strategic plans for enhancing T\&L quality. The first research question is: How is strategic management and planning organised at Croatian HEIs and is it effective?

Hsu et al. (2016) noted that the teaching construct is important determinant of service quality in higher education because the core service at HEI is lecture given by a teacher. Teaching process is recognised as a critical dimension for describing the quality at the HEI (Chen et al., 2014; Owlia \& Aspinwall, 1996; Osseo-Assare \& Longbottom, 2002). Langstrand et al. (2015) argue that much teaching is still centred around what teacher does and a logic of learning that is based on passive reception of knowledge. Although student-centred teaching has been promoted in studies since 1980s (Astin, 1984) the problem still exist. Astin (1984) suggested that teachers should focus on what student does and he developed theory of student involvement as a key factor for learning improvement. Some recent studies highlighted the need to implement more systematic approach to higher education service quality relating T\&L studies with studies of quality management (Douque, 2014; Dužević et al., 2016; Manatos et al., 2017). To provide 
better service for students, HEIs must understand students' temporary and future needs to attract, encourage and maintain stronger relationships with students (Hsu et al., 2016). To find out if student-centred learning is recognised in Croatian higher education system, second research question is: How is student-centred learning promoted and implemented at Croatian HEIs?

Leadership is crucial for T\&L quality enhancement, and for the relevance and success of HEIs (Hofmeyer et al., 2015). Leadership in higher education should be more flexible (Bamber \& Anderson, 2012) with democratic organizational culture and shared responsibilities among employees (Hofmeyer et al., 2015). To achieve sustainable success and improve their T\&L processes, HEIs should focus on: leadership based on the strategic directions; regular, flexible and comprehensive planning; regular monitoring of organizational culture; continuous evaluation of improvement actions; strategic agility needed to promote innovation among all employees (Barnard \& Van der Merwe, 2016). They should also implement innovative practices in higher education T\&L that are based on student-centred learning approach. According to Hsu et al. (2016) student centred learning emphasises students' role in discovery and construction of knowledge and it strengthens student motivation and responsibility, promotes communication and team spirit, and builds student-teacher relationships. The need to implement innovative practices in T\&L is recognised in many studies (Asif \& Searcy, 2014; Bamber \& Anderson, 2012; Chen, Chen \& Chen, 2014; Dee Fink, 2013; Hernandez, 2012; Iwakami Beltrão \& Barçante, 2016; Kirkwood \& Price, 2014; Suárez-Barraza \& RodríguezGonzález, 2015; Wisniewska \& Grudowski, 2016). ). Teaching innovation implies teacher's use of multi-faceted and lively teaching methods, and diversified and rich content to stimulate students' interest in learning (Wu, 2002). According to Lin (2002) teaching innovation involves teachers having open mind, having the ability to reflect on teaching and being able to use the cognitive skills of reflection, questioning, deconstruction and reconstruction to guide students learning and critical thinking. Innovations in T\&L process may be part of the continuous improvement process (such as introduction of new methods in teaching) or some radical changes (such as complete change in infrastructure for teaching or in curriculum). According to Fidalgo-Blanco, Sein-Echaluce \& García-Peñalvo, (2014) innovation is a strategic option that creates knowledge and its management is necessary. Innovation occurs only when knowledge is transferred, regardless what is stated in HEI's strategy. Thus, management should implement practices that will enable transferring knowledge from experts to novices, sharing the most relevant information and using resources more efficiently (FidalgoBlanco et al., 2014). Therefore, third research question seeks to reveal the most important innovative practices that can be used to enhance T\&L quality: What innovative practices are implemented in Croatian HEIs and what are the most critical practices for T\&L enhancement?

\section{METHODS}

This study relied on the combined research methods. First phase included quantitative empirical research using on-line survey to collect data about the management 
perceptions of their institutional framework and practices for T\&L quality enhancement. Second phase was qualitative research combining in depth analysis of HEIs strategies and plans for T\&L development and interviews with the managers and young teachers from 11 Croatian HEIs.

\subsection{Quantitative research design}

The survey instrument was developed after the comprehensive literature review. It consisted of the three main constructs: (1) institutional framework for T\&L quality enhancement, (2) promotion of the T\&L quality at the HEI, and (3) practices for T\&L quality enhancement. The first construct consisted of several claims regarding the existing institutional framework for T\&L enhancement, and respondents should answer if it is relevant for their HEI, choosing from: yes, no, or don't know. Institutional framework for T\&L quality enhancement is management framework that consists of HEI's strategy, objectives and plans, and learning outcomes. Strategy is an instrument used by the HEI's management to manage processes and to deal with the environmental challenges in order to choose portfolio of activities and determine their position in the higher education system (Fumasoli \& Lepori, 2011). Therefore, leadership is considered a key factor for T\&L quality improvement in the higher education (Barnard \& Van der Merwe, 2016; Hofmeyer et al., 2015; Smith, 2012). The most important elements of the institutional framework include: emphasising T\&L quality as one of the key strategic objectives, established interconnected processes for the realization of strategic objectives related to $\mathrm{T} \& \mathrm{~L}$, the necessary teaching competencies defined, a system for the development and enhancement of T\&L quality (Barnard and Van der Merwe, 2016; Gray and Radloff, 2010; Hofmeyer et al., 2015; OECD, 2012). The second construct consisted of several statements related to the level of promotion of T\&L at the HEI, and respondents' perceptions were evaluated on the 5 point Likert scale. Promotion of the T\&L quality included items such as: compliance of the T\&L with student assessments (Hernandez, 2012; Mostrom and Blumberg, 2012), support for the teachers (Bamber and Anderson, 2012; Barnard and Van der Merwe, 2016; Dochy et al., 2011; Georgeta, Cano \& Cabrera, 2016), rewards and recognitions for teaching excellence (Willingham-McLain; 2015), communication systems (Smith, 2012), memberships in the networks in the area of T\&L development (Smith, 2012), inclusion of T\&L aspects in the evaluations of the HEI (OECD, 2012). Third construct consisted from the list of practices for T\&L quality enhancement and respondents were asked to rate the frequency of use on the 5 point Likert scale (from 1-never to 5 -always). To test the reliability and validity of the instrument it has been distributed to the academic experts from the field of T\&L quality and adjusted according to their suggestions. The pilot research on the teachers and managers from several Croatian higher education institutions was conducted resulting in minor changes.

All HEIs in Croatia were included in the study. According to the data from Ministry of Science and Education there were 171 HEIs in 2017. The survey was distributed to the two representatives of the management at each HEI (rector or dean and vice-rector or vice-dean responsible for teaching quality). Data were collected from February to April 2017. In total, 135 complete answers were collected resulting in the 
return rate of $38,47 \%$. Table 1 presents the sample structure and further analysis confirmed high compatibility with the population.

Table 1. Structure of the sample

\begin{tabular}{|l|l|l|}
\hline & Number of answers & Share (\%) \\
\hline Ownership of the HEI & Public (115) & $85,19 \%$ \\
& Private (20) & $14,81 \%$ \\
\hline Type of the HEI & University constituent units (102) & $75,60 \%$ \\
& Colleges (18) & $13,30 \%$ \\
& Polytechnics (15) & $11,10 \%$ \\
\hline Scientific field(s) & Natural Sciences (17) & $7,56 \%$ \\
& Technical Sciences (42) & $18,67 \%$ \\
& Biomedicine and Health (19) & $8,44 \%$ \\
& Biotechnical Sciences (16) & $7,11 \%$ \\
& Social Sciences (60) & $26,67 \%$ \\
& Humanities (31) & $13,78 \%$ \\
& Artistic areas (14) & $6,22 \%$ \\
& Interdisciplinary Science (25) & $11,11 \%$ \\
& Interdisciplinary area of art (1) & $0,04 \%$ \\
\hline \multirow{5}{*}{ TOTAL } & $\mathbf{1 3 5}(\mathbf{3 9 , 4 7 \% )}$ & \\
\hline
\end{tabular}

\subsection{Qualitative research design}

Qualitative research consisted of detailed analysis of the websites and strategic documents (strategy, strategic plans, quality plans, policies, external evaluation reports from Agency for Science and Higher Education etc.) of 11 HEIs in Croatia followed by structured interviews with the management (deans or vice-deans responsible for teaching quality). Young teachers (employed at the HEI in the last five years) were also interviewed to compare their perceptions with the management. The interviews were recorded using the audio track. After finishing the transcripts from the interviews, data were encoded and categorised in three areas: (1) institutional framework for T\&L quality enhancement, (2) practices for T\&L quality enhancement, (3) possibilities for the implementation of T\&L practices at Croatian HEIs.

\section{ANALYSIS AND RESULTS}

\subsection{Quantitative research analysis and results}

Results from the quantitative research revealed that almost all HEIs have emphasised T\&L quality as their strategic goal $(95,6 \%)$. As can be seen from the table 2 most of the Croatian HEIs $(77,8 \%)$ have established an institutional framework for T\&L quality enhancement. In addition, $60 \%$ of HEIs defined needed teachers' competences and provided support for development of T\&L through special organizational unit. 
Table 2. Institutional framework for T\&L quality enhancement

\begin{tabular}{|l|l|l|l|}
\hline \multirow{2}{*}{ Elements of the system } & \multicolumn{2}{l|}{ Answer } \\
\cline { 2 - 4 } & Yes & No & $\begin{array}{l}\text { Don't } \\
\text { know }\end{array}$ \\
\hline $\begin{array}{l}\text { T\&L quality is emphasised as one of strategic } \\
\text { goals at HEI. }\end{array}$ & $\begin{array}{l}129 \\
(95,6 \%)\end{array}$ & $4(3,0 \%)$ & $2(1,5 \%)$ \\
\hline $\begin{array}{l}\text { Institutional framework for T\&L quality } \\
\text { enhancement is established at HEI. }\end{array}$ & $\begin{array}{l}105 \\
(77,8 \%)\end{array}$ & $\begin{array}{l}18 \\
(13,3 \%)\end{array}$ & $\begin{array}{l}12 \\
(8,9 \%)\end{array}$ \\
\hline $\begin{array}{l}\text { Teacher competences for all teachers at HEI are } \\
\text { clearly defined. }\end{array}$ & $\begin{array}{l}81 \\
(60,0 \%)\end{array}$ & $\begin{array}{l}31 \\
(23,0 \%)\end{array}$ & $\begin{array}{l}23 \\
(17,0 \%)\end{array}$ \\
\hline $\begin{array}{l}\text { There is organizational unit that provides support } \\
\text { for development of T\&L quality at HEI. }\end{array}$ & $\begin{array}{l}81 \\
(60,0 \%)\end{array}$ & $\begin{array}{l}43 \\
(31,9 \%)\end{array}$ & $\begin{array}{l}11 \\
(8,1 \%)\end{array}$ \\
\hline
\end{tabular}

Promotion of T\&L quality development was tested with second set of questions. Results (figure 1) pointed to critical factors for the improvement: (1) recognition and rewards for teaching excellence, (2) involvement in national, regional, and international networks for T\&L quality development, (3) use of communication channels to emphasise the importance of T\&L quality development.

Figure 1. Promotion of T\&L quality

$\mathrm{HEl}$ is involved in national, regional, and international networks.

HEI use different means of communication to emphasise importance of teaching and..

Teaching and learning quality is included in institutional evaluations.

HEI established system for rewarding teaching excellence.

HEI supports and encourage teacher to adopt innovative teaching practices.

HEI provide support for teachers to improve teaching and learning quality.

Teaching and learning processes are adjusted with student assessments.

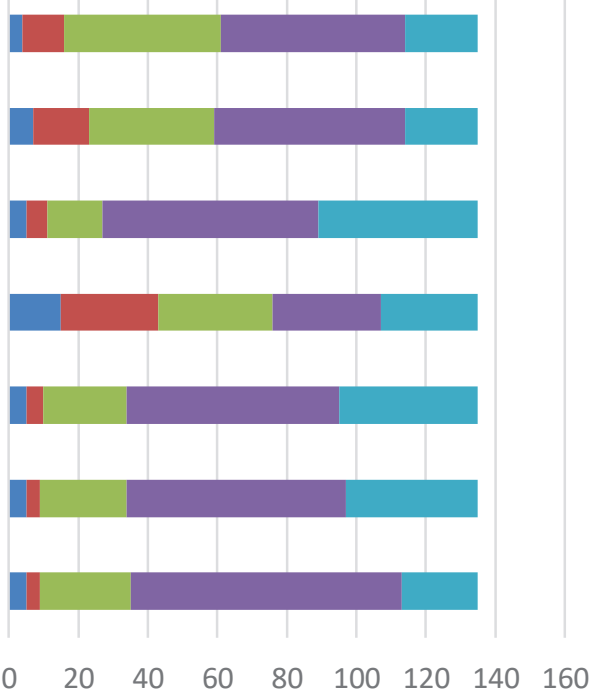

Fully disagree Disagree

Neither agree nor disagree 
Differences in perceptions of management from public and private HEIs was analysed using t-test and significant difference was found only for the item related to adjustment of $T \& L$ processes with student assessments $(T=20529, p=0,013)$. In general, managers from private HEIs rated all promotion activities higher than managers from public HEIs. Multivariate analysis of variance was used to test the differences between three types of HEIs, and significant difference was found only for item related to provided support for teachers to improve T\&L quality $(F=4,796, p=0,010)$. More detailed analysis, based on Tukey's post hoc test showed that only universities' constituent units and polytechnics differ in their perception of provided support.

Final section of the survey included items related to the frequency of application of T\&L quality enhancement at HEIs (figure 2). The most common practices at Croatian HEIs are: mentoring young teachers, trainings for teachers, internal programs and workshops. Practices that are not frequently implemented at Croatian HEIs are: online learning for teachers, professional communication and networking, recruitment of professional teams for the development of T\&L quality, peer reviews, and structured professional materials. Analysis also included differences in use of practices for T\&L quality enhancement with regard to ownership status of HEIs. T-tests confirmed existence of significant differences for all practices $(p<0,05)$, except for online learning. The differences between HEIs with regard to the type were tested using multivariate analysis of variance. Results confirmed significant differences in following items: professional teams $(\mathrm{F}=3,185, \mathrm{p}=0,045)$, mentoring young teachers $(\mathrm{F}=3,582, \mathrm{p}=0,031)$, trainings for teachers $(\mathrm{F}=3,446, \mathrm{p}=0,035)$, recruitment of external experts $(\mathrm{F}=8,603, \mathrm{p}=0,000)$, external workshops and education $(\mathrm{F}=9,205, \mathrm{p}=0,000)$, study visits $(\mathrm{F}=3,478, \mathrm{p}=0,034)$, professional communication and networking $(\mathrm{F}=4,076, \mathrm{p}=0,019)$. Further analysis using Tukey's post hoc test showed minor differences for most of the items, with more significant differences between university constituent units and colleges regarding recruitment of external experts and external workshops and education. 
Figure 2. Practices for T\&L quality enhancement

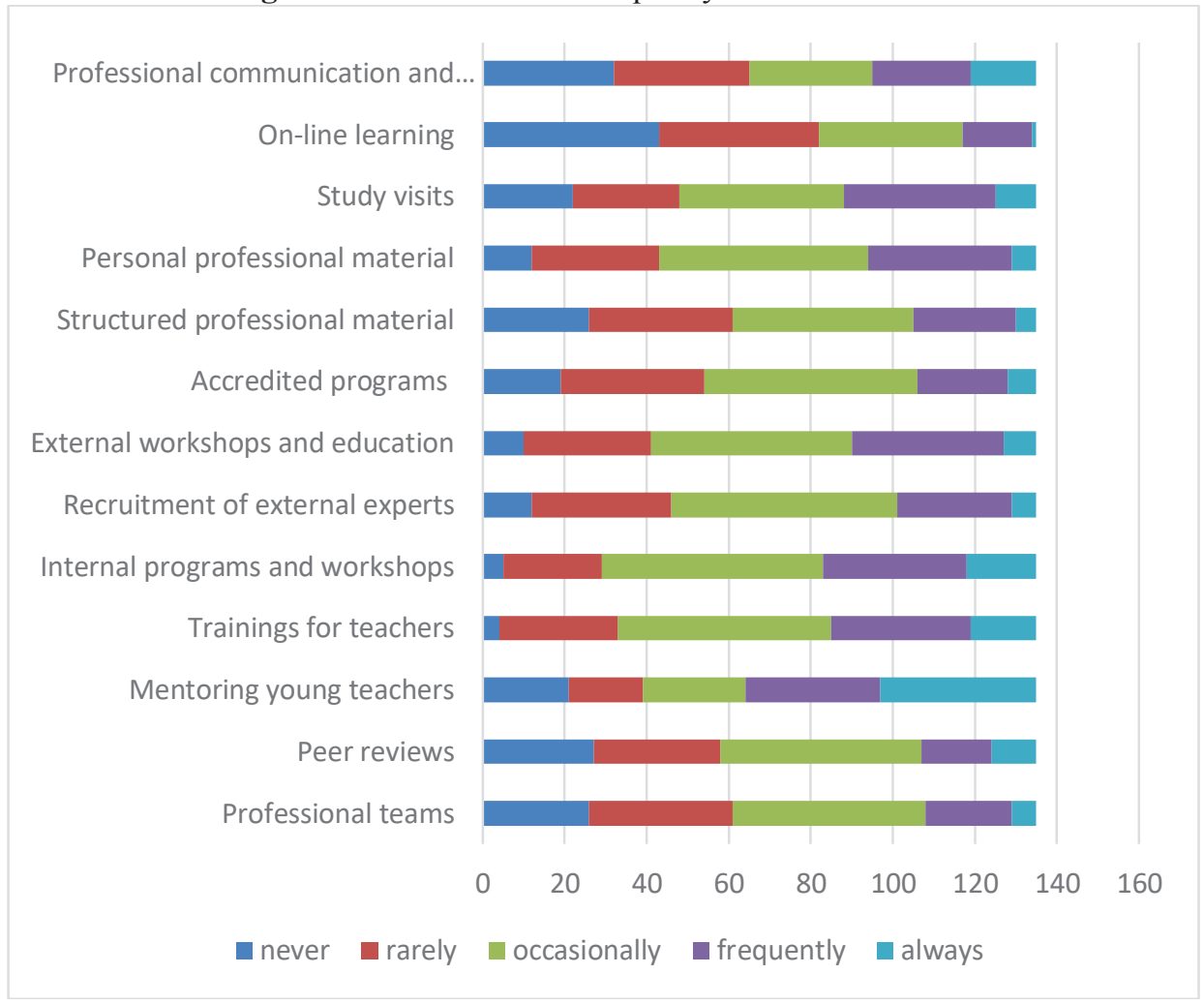

\subsection{Qualitative research results}

Qualitative research showed that Croatian HEIs have been developing strategies and plans for T\&L quality enhancement to keep up with contemporary education systems. However, more detail insight into their institutional frameworks and strategic plans revealed that they mostly focus on quantitative indicators and that T\&L processes are usually assessed only using student surveys. All HEIs have implemented additional methods for evaluating T\&L, but it is used occasionally and on a voluntary basis. This is not enough to achieve continuous improvement and systematic approach to evaluations is needed. Analysis of the HEIs' strategic documents and plans indicated that plans are often incomplete and non-informative for the internal stakeholders, for example some plans didn't include student assessment issues. Moreover, roles and responsibilities for defined actions and methods for the evaluation and monitoring are often not clearly addressed. In addition, documents are not fulfilling their goals regarding raising awareness about the need for $T \& L$ quality enhancement and motivating teachers to engage more in the improvement actions. Similar results were found in Australian higher 
education (Gray \& Radloff, 2010).

Second construct in the qualitative research were practices for T\&L quality enhancement. All HEIs highlighted their engagement in different practices for T\&L enhancement. The results for management and young teachers are compared in the following table. Most of the practices for T\&L quality enhancement stated by the management were also emphasised in the interviews with young teachers.

Table 3. Practices for T\&L quality enhancement

\begin{tabular}{|l|c|c|}
\hline Practices & Management & $\begin{array}{l}\text { Young } \\
\text { teachers }\end{array}$ \\
\hline Courses for the improvement of pedagogical competence & $\checkmark$ & $\checkmark$ \\
\hline Projects aimed at T\&L quality development & $\checkmark$ & $\checkmark$ \\
\hline $\begin{array}{l}\text { Infrastructure for the implementation of innovative T\&L } \\
\text { practices }\end{array}$ & $\checkmark$ & $\checkmark$ \\
\hline Mentoring of the young teachers & $\checkmark$ & $\checkmark$ \\
\hline External experts recruitment & $\checkmark$ & $\checkmark$ \\
\hline Communication systems at the HEI & $\checkmark$ & $\checkmark$ \\
\hline Structured professional materials & $\checkmark$ & $\checkmark$ \\
\hline Workshops at the HEI & $\checkmark$ & $\checkmark$ \\
\hline Study visits and comparison with good practices & $\checkmark$ & $\checkmark$ \\
\hline Recognitions and rewards for teaching excellence & & $\checkmark$ \\
\hline Peer review & $\checkmark$ & $\checkmark$ \\
\hline Cooperation with the practice and business environment & & $\checkmark$ \\
\hline Student Surveys & & \\
\hline Professional meetings, symposiums and conferences & \\
\hline
\end{tabular}

Regarding the improvement possibilities and innovative practices that could be implemented in Croatian HEIs to enhance T\&L quality, most of the respondents emphasised a shift towards learning-centred teaching and practices aimed at empowering teachers to adjust their teaching methods accordingly. Ellis (2015) also found that learning-centred teaching is still not widely implemented in higher education, regardless the fact that they improve student learning and students perceive them as innovations in teaching. The most important innovative practices, from the management perspective, were different on-line learning methods and investments into technologies that support their implementation. Modern information technologies are necessary precondition for the implementation of innovative teaching methods (Georgeta et al., 2016; Kirkwood \& Price, 2014). The role of teachers (from service provider to manager role) and the role of student (information is not the aim but mean for mastering skills in professional activities) changed with the implementation of innovative teaching methods (Klyap \& Klyap, 2016). Management in the higher education must be aware of changed roles and provide support for smooth running of changes and adjustment of T\&L processes (Hofmeyer et al., 2015; Nordstrom \& Korpelainen, 2011; Smith, 2012). In addition, some respondents highlighted the application of problem based learning methods through interactive workshops. Literature strongly support the idea of using problem based learning as an innovative teaching method (Dee Fink, 2013; Dochy et al., 2011; Georgeta et al., 2016; 
Hernandez, 2012; Hockings, Brett \& Terentjevs., 2012; Mostrom \& Blumberg, 2012; Ning \& Downing, 2010; Nordstrom \& Korpelainen, 2011).

Recognition and rewards were also recognised as a tool for T\&L quality enhancement. Most of the HEIs have some recognition and reward system, but it is focused on the scientific and research area or on the students' ratings from the student satisfaction survey results. Only two HEIs established reward system for teaching excellence that is based on a set of quality indicators. For example, at one HEI they use peer-reviews, self-assessment analysis, results from student surveys, and results from teaching material evaluations. Based on the research findings, it would be useful to develop adequate reward systems for teaching excellence because it promotes innovative practices in teaching and have strong positive influence on performance evaluation and teaching excellence recognition (Willingham-McLain, 2015).

One of the key issues for the improvement of Croatian HEIs' T\&L quality, raised from the interview, was lack of internal communication system to promote the importance of T\&L quality enhancement. This issue has been highlighted in many previous studies that revealed the need to develop efficient communication strategy as essential precondition for the implementation of innovative practices in T\&L processes (Bamber \& Anderson, 2012; Fumasoli \& Lepori, 2011; Hofmeyer et al., 2015; Smith, 2012). Except information available on HEI's website, internal documents, and occasional seminars and workshops for T\&L development, most HEIs have not established the system for informing and motivating teachers. Nevertheless, there are some good practices where T\&L quality is a part of regular discussions at formal and informal meeting of the teachers at different levels at the HEI. Working groups are formed at some HEIs to discuss and evaluate T\&L quality and to share the results with other teachers during the Faculty Council meetings.

With regard to the Croatian HEIs' involvement in regional and international networks aimed at T\&L development, all HEIs pointed out their inclusion in teacher exchange programs and partnerships with the labour market organizations, while one HEI mentioned formal cooperation with regional organizations, and one HEI the project with international partners from USA aimed at educating teachers and developing their competencies. Since networks may ease diffusion of innovative practices in T\&L (Smith, 2012), Croatian HEIs should involve more in regional and international networks.

Further analysis was focused on exact plans for T\&L quality enhancement at Croatian HEIs. The most frequently mentioned plans referred to: internationalization of teaching content and introduction of courses in English, and providing support for teachers to implement innovative practices and to improve curriculum. Although the study found that internal communication systems are not developed, detailed analysis of future plans revealed that management recognised the issue and they have specific improvement plans.

Key barriers for the implementation of innovative practices in T\&L for Croatian HEIs are: (1) inadequate procedures and regulatory framework in the national higher education system in which the emphasis is placed on scientific and research work, and teaching quality is marginalized, (2) financing of innovative practices and supportive 
systems, especially at public HEIs, (3) high teachers' workloads that doesn't leave them time to implement innovation, (4) some teachers' resistance to change.

\section{DISCUSSION}

Modern education systems are based on strategies and plans for quality improvement. T\&L quality is essential for all HEIs striving to achieve sustainable success in today's dynamic environment. Leadership and management are necessary in formal academic governance and individuals who perform these roles strongly influence T\&L culture (Hofmeyer et al., 2015). This study analysed quality enhancement practices related to T\&L to examine how specific practices may contribute to the achievement of HEI's strategy for T\&L development.

Quantitative research found that almost all Croatian HEIs include T\&L quality in their strategies and plans, but institutional frameworks for their realization are not efficient. More detailed insight is obtained by qualitative research which showed that managers form Croatian HEIs understand the importance of strategic approach to T\&L development, but their feedback system is usually based on a set of quantitative indicators that doesn't provide enough information for major improvements. Furthermore, strategies are written in style that doesn't fulfil their aim to motivate internal stakeholders (students and teachers) and to inform external stakeholders about T\&L developments. HEIs could use their strategies as a tools for motivating, engaging and informing their stakeholders. Well structured strategies for T\&L may lead and motivate teachers, and to some extent students, to enhance their T\&L practices (Gray \& Radloff, 2010). For external stakeholders, including: the general public, future students and employers, business community and professional bodies, and government; T\&L strategies may be used to: (1) emphasise T\&L as HEI's core activity, (2) provide evidence of commitment to continuous improvement, (3) demonstrate the ability to progress and show success, (4) disclose accountability towards the taxpayers, (5) inform donors about resource allocation, (6) prove compliance with legal framework and management structure (Gray \& Radloff, 2010). Management of the HEI may use quality management system, such as: ISO 9001, EFQM model, Kaizen to lead their efforts towards continuous quality improvement (Campatelli et al., 2011; Chen et al., 2017; Sadeh \& Garkaz, 2015; Suárez-Barraza \& Rodríguez-González, 2015). The quality management system, based on systematic approach to managing HEI's processes, might contribute to higher standards of the core service performance, i.e. T\&L (Pérez Rave \& Muñoz Giraldo, 2016).

Promotion of T\&L quality enhancement is very important for empowering and motivating teachers to engage more in innovative T\&L practices (Bernard \& Van der Merwe, 2016; Kashif, Ramayah \& Sarifuddin, 2016; Smith, 2012). Results showed that Croatian HEIs have tremendous improvement opportunities. Critical factors to realize improvements are: use of internal communication channels to emphasise the importance of T\&L quality, formation of systems to reward teaching excellence, and more involvement in regional and international networks aimed at T\&L development. HEIs should use their strategies and plans to promote the importance of T\&L quality and to 
engage their teachers in enhancement activities. Committed, active, innovative teachers who use modern methods in teaching are essential for T\&L quality enhancement (Wisnievska \& Grudowski, 2016).

With regard to the practices for $\mathrm{T} \& \mathrm{~L}$ quality enhancement, improvements are possible in following areas: on-line learning for teachers, professional communication and networks, recruitment of professional teams for T\&L development, peer-reviews, and structured professional materials. More detailed analysis of innovative practices in T\&L at Croatian HEIs indicated strong focus on technology application and different forms of on-line learning, and adaptation of modern teaching methods focused on problem based learning through interactive workshops. HEIs should shift towards student-centred learning and providing systematic support to their teachers to implement innovative practices in their teaching (Kashif et al., 2016; Mostrom \& Blumberg, 2012; Nordstrom \& Korpelainen, 2011). Internal communication system, used for motivating and empowering teachers to engage more in T\&L quality development is a key for sustainable success (Bamber \& Anderson, 2012; Barnard \& Van der Merwe, 2016; Hofmeyer et al., 2015). Furthermore, involvement in regional and international networks to share the experiences and good practices may help in innovation diffusion (Smith, 2012).

\section{CONCLUSION AND IMPLICATIONS}

The study examined innovative practices used for T\&L quality enhancement in Croatian higher education system. Mixed methods were used to reveal how specific innovations influence T\&L quality and what strategic actions stimulate such innovations. Results indicate that strategic plans for enhancing T\&L quality don't fulfil their aim to provoke teachers' and students' engagement.

Finally, the set of guidelines for HEI's management that may be useful for achieving continuous development of T\&L quality include: (1) supportive leadership based on the T\&L strategies that are informative for external stakeholders and motivating for internal stakeholders, and with clearly stated responsibilities and evaluation measures (use of quality management systems may help managers in achieving this difficult task); (2) promoting $T \& L$ quality enhancement at higher education institution through effective internal communication channels, involvement in regional and international networks for T\&L development, establishing transparent system for rewarding teaching excellence; (3) support teachers in developing their skills and competences for the implementation of innovative teaching practices; (4) maintain institutional infrastructure and environment to support innovative practices; (5) create democratic culture based on collaborative engagement to empower teachers to become agents of change.

\section{LIMITATIONS AND FUTURE RESEARCH}

The results of this study should be considered with regard to some limitations. The research was conducted in Croatian higher education context and cannot be 
generalised to other higher education systems. However, the integration of different approaches to quality enhancement is important for every HEI, and proposed set of guidelines may be useful in different contexts. In addition, the study focused on the management perceptions of the T\&L quality that can be subjective. Future studies should test our findings in other higher education contexts and may include views from other relevant stakeholders.

\section{REFERENCES:}

1. Asif, M., Searcy, C. (2014). Determining key capabilities required for performance excellence in higher education. Total Quality Management \& Business Excellence,25(1), 22-35. DOI: 10.1080/14783363.2013.807676

2. Astin, A. W. (1984). Student involvement: A developmental theory for higher education. Journal of College Student Personnel, 25(4), 297-308.

3. Bayraktar, E., Tatoglu, E., Zaim, S. (2008). An instrument for measuring the critical factors of TQM in Turkish higher education. Total Quality Management \& Business Excellence, 19(6), 551-574. DOI: 10.1080/14783360802023921

4. Bamber, V., Anderson, S. (2012). Evaluating learning and teaching: institutional needs and individual practices. International Journal of Academic Development, 17(1), 5-18. DOI: 10.1080/1360144X.2011.586459

5. Bernard, Z., Van der Merwe, D. (2016). Innovative management for organizational sustainability in higher education. International Journal of Sustainability in Higher Education, 17(2), 208-227. DOI: 10.1108/IJSHE-08-2014-0120

6. Bovill, C., Cook-Sather, A., Felten, P., Millard, L., Moore-Cherry, N. (2016). Addressing potential challenges in co-creating learning and teaching: overcoming resistance, navigating institutional norms and ensuring inclusivity in student-staff partnerships. Higher Education, 71, 195-208. DOI: 10.1007/s10734-015-9896-4

7. Campatelli, G., Citti, P., Meneghin, A. (2011). Development of a simplified approach based on the EFQM model and Six Sigma for the implementation of TQM principles in a university administration. Total Quality Management \& Business Excellence, 22(7), 691-704. DOI: 10.1080/14783363.2011.585755

8. Chen, C-Y., Chen, P-C., Chen, P-Y. (2014). Teaching quality in higher education: An introductory review on a process-oriented teaching-quality model. Total Quality Management \& Business Excellence, 25(1), 36-56. DOI: 10.1080/14783363.2011.637789

9. Chen, I-S., Chen, J-K., Padró, F.F. (2017). Critical quality indicators of higher education. Total Quality Management \& Business Excellence, 28(1-2). 130-146. DOI: $10.1080 / 14783363.2015 .1050178$

10. Dee Fink, L. (2013). Innovative Ways of Assessing Faculty Development. New Directions for Teaching and Learning, 133, 47-59. DOI: 10.1002/t1.20045

11. Dochy, F., Berghmans, I., Kyndt, E., Baeten, M. (2011). Contributions to innovative learning and teaching? Effective research-based pedagogy - a response to TLRP's 
principles form a European perspective. Research Papers in Education, 26(3), 345356. DOI: $10.1080 / 02671522.2011 .595545$

12. Duque, L.C. (2014), A framework for analyzing higher education performance: students' satisfaction, perceived learning outcomes, and dropout intention. Total Quality Management and Business Excellence, 25(1-2), 1-21. DOI: 10.1080/14783363.2013.807677

13. Dužević, I., Mikulić, J., Baković, T. (2016). An Extended Framework for Analysing Higher Education Performance. Total Quality Management and Business Excellence, DOI: 10.1080/14783363.2016.1224083

14. Ellis, D.E. (2015). What Discourage Students from Engaging with Innovative Instructional Methods: Creating a Barrier Framework. Innovations in Higher Education, 40, 111-125. DOI: 10.1007/s10755-014-9304-5

15. Fidalgo-Blanco, A., Sein-Echaluce, M.L., García-Peñalvo, F.J. (2014). Knowledge Spirals in Higher Education Teaching Innovation. International Journal of Knowledge Management, 10(4), 22. DOI: 10.4018/ijkm.2014100102

16. Fumasoli, T., Lepori, B. (2011). Patterns of strategies in Swiss higher education institutions. Higher Education, 61, 157-178. DOI: 10.1007/s10734-010-9330-x

17. Georgeta, I., Cano, E., Cabrera, N. (2016). Competency Assessment Tool (CAT). The evaluation of an innovative competency-based assessment experience in higher education. Technology, Pedagogy and Education, 25(5), 631-648. DOI: 10.1080/1475939X.2015.1134635

18. Gray, K., Radloff, A. (2010). What's it all about? Making sense of Australian university learning and teaching plans. Higher Education Research \& Development, 29(3), 291-305. DOI: 10.1080/07294360903532024

19. Hernandez, R. (2012). Does continuous assessment in higher education support student learning? Higher Education, 64, 489-502. DOI: 10.1007/s 10734-012-95067

20. Hockings, C., Brett, P., Terentjevs, M. (2012). Making a difference - inclusive learning and teaching in higher education through open educational resources. Distance Education, 33(2), 237-252. DOI: 10.1080/01587919.2012.692066

21. Hofmeyer, A., Sheingold, B.H., Klopper, H.C., Warland, J. (2015). Leadership in Learning and Teaching in Higher Education: Perspectives of Academics in Nonformal Leadership Roles. Contemporary Issues in Education Research, 8(3), 181192. DOI: $10.19030 /$ cier.v8i3.9348

22. Hrnčiar, M., Madzik, P. (2017). A 3D view of issues of quality in higher education. Total Quality Management \& Business Excellence, 28(5), 633-662. DOI: 10.1080/14783363.2015.1105100

23. Hsu, S-H., Wang, Y-C., Cheng, C-J., Chen, Y-F. (2016). Developing a decomposed alumni satisfaction model for higher education institutions. Total Quality Management \& Business Excellence, 27(9-10), 979-996. DOI: 10.1080/14783363.2015.1054102

24. Iwakami Beltrão, K., Barçante, L.C. (2016). Teaching principles and fundamentals of business excellence to undergraduate students through a game. Total Quality 
Management \& Business Excellence, 27(5-6), 381-698. DOI: 10.1080/14783363.2015.1043116

25. Jaca, C., Psomas, E. (2015). Total quality management practices and performance outcomes in Spanish service companies. Total Quality Management \& Business Excellence, 26(9-10), 958-970. DOI: 10.1080/14783363.2015.1068588

26. Kashif, M., Ramayah, T., Sarifuddin, S. (2016). PAKSERV - measuring higher education service quality in a collectivist cultural context. Total Quality Management \& Business Excellence, 27(3-4), 265-278. DOI: 10.1080/14783363.2014.976939

27. Kirkwood, A., Price, L. (2014). Technology-enhanced learning and teaching in higher education: what is 'enhanced' and how do we know? A critical literature review. Learning, Media and Technology, 39(1), 6-36. DOI: 10.1080/17439884.2013.770404

28. Klyap, M., Klyap, M. (2016). Innovative directions of the higher education of Ukraine, Studia Universitatis ,,Vasile Goldis “ Arad. Economics Series, 26(4), 5466. DOI: 10.1515/sues-2016-0019

29. Lazibat, T., Baković, T., Dužević, I. (2014). How perceived service quality influences student satisfaction? Teachers' and students' perspectives. Total Quality Management and Business Excellence, 25(8), 923-934. DOI: 10.1080/14783363.2014.916036

30. Lane, P., Hunt, J., Farris, J. (2011). Innovative teaching to engage and challenge twenty-first century entrepreneurship students: An interdisciplinary approach. Journal of Entrepreneurship Education, 14, 105-123.

31. Langstrand, J., Cronemyr, P., Poksinska, B. (2015). Practise what you preach: quality of education in education on quality. Total Quality Management \& Business Excellence, 26(11-12), 1202-1012. DOI: 10.1080/14783363.2014.925290

32. Lin, I.M. (2002). Innovative teaching - starting from the professional ethics of teaching. Secondary Education, 4, 36-49.

33. Manatos, M.J., Sarrico, C.S., Rosa, M.J. (2017). The integration of quality management in higher education institutions: a systematic literature review. Total Quality Management \& Business Excellence, 28(1-2), 159-175. DOI: 10.1080/14783363.2015.1050180

34. Mikulić, J., Dužević, I., Baković, T. (2015). Exploring drivers of student satisfaction and dissatisfaction: An assessment of impact-asymmetry and impact-range. Total Quality Management and Business Excellence, 26(11-12)., 1213-1225. DOI: 10.1080/14783363.2014.925291

35. Mostrom, A.M., Blumberg, P. (2012). Does Learning-Centered Teaching Promote Grade Improvement? Innovations in Higher Education, 37(5), 397-405. DOI: 10.1007/s10755-012-9216-1

36. Ning, H.K., Downing, K. (2010). The impact of supplemental instruction on learning competence and academic performance. Studies in Higher Education, 35(8), 921-939. DOI: 10.1080/03075070903390786 
37. Nordstrom, K., Korpelainen, P. (2011). Creativity and inspiration for problem solving in engineering education. Teaching in Higher Education, 16(4), 439-450. DOI: $10.1080 / 13562517.2011 .560379$

38. OECD (2012). Fostering Quality Teaching in Higher Education: Policies and Practices. OECD Publishing.

39. Osseo-Asare, A.E.; Longbottom, D. (2002). The need for education and training in the use of the EFQM model for quality management in UK higher education institutions, Quality Assurance in Education, 10(1), 26-36. DOI: 10.1108/09684880210416085

40. Owlia, M.S., Aspinwall, E.M. (1996). A framework for the dimensions of quality in higher education, Quality Assurance in Education, 4(2), 12-20. DOI: 10.1108/09684889610116012

41. Pérez Rave, J., Muñoz Giraldo, L. (2016). ClassroomQual: a scale for measuring the use-of-classrooms-for-teaching-learning service quality. Total Quality Management \& Business Excellence, 27(9), 1063-1090. DOI: 10.1080/14783363.2015.1060850

42. Rosa, M. J., Sarrico, C. S., Amaral, A. (2012). Implementing quality management systems in higher education institutions. In M. Savsar (Ed.), Quality assurance and management, (pp. 129-146). Rijeka: InTech. DOI: 10.5772/33922

43. Sadeh, E., Garkaz, M. (2015). Explaining the mediating role of service quality between quality management enablers and students' satisfaction in higher education institutes: the perception of managers. Total Quality Management \& Business Excellence, 26(11-12), 1335-1356. DOI: 10.1080/14783363.2014.931065

44. Smith, K. (2012). Lessons learnt from literature on the diffusion of innovative learning and teaching practices in higher education, Innovations in Education and Teaching, 49(2), 173-182. DOI: 10.1080/14703297.2012.677599

45. Suárez-Barraza, M.F., Rodríguez-González. F.G. (2015). Bringing Kaizen to classroom: lessons learned in an Operations Management course. Total Quality Management \& Business Excellence, 26(9-10), 1002-1016. DOI: $10.1080 / 14783363.2015 .1068594$

46. Willingham-McLain, L. (2015). Using a scholarship of teaching and learning approach to award faculty who innovate. International Journal for Academic Development, 20(1), 58-75. DOI: 10.1080/1360144X.2014.995661

47. Wisniewska, M., Grudowski, P. (2016). High-quality academic teachers in business school. The case of The University of Gdańsk, Poland. Total Quality Management \& Business Excellence, 27(10), 1158-1170. DOI: 10.1080/14783363.2015.1064766

48. Wu, C.S. (2002). Important concept and implementation strategy of creative teaching. Taiwan Education, 614, 2-8. 


\title{
POTICANJE INOVACIJA U UČENJU I POUČAVANJU RADI UNAPRJEĐENJA KVALITETE VISOKOG OBRAZOVANJA
}

\author{
Ines Dužević ${ }^{4}$, Tomislav Baković ${ }^{5}$ \& Mia Delićc
}

\section{Sažetak}

Svrha ovog rada je istražiti inovativne prakse koje se mogu koristiti kao alat za unaprjeđenje kvalitete visokog obrazovanja. Konkretnije, rad analizira kako specifične inovacije doprinose ostvarenju strateških ciljeva te otkriva koje su najznačajnije prakse visokih učilišta primijenjene u realizaciji tih ciljeva. Istraživanje je provedeno u dvije faze: anketno istraživanje i strukturirani intervjui s vodstvom visokih učilišta. Anketno istraživanje je provedeno u svrhu određivanja razine inovativnosti i aktivnosti strateškog planiranja koje su implementirane na hrvatskim visokim učilištima. Ukupno je 135 članova vodstva odgovorilo na upitnik. Druga faza je uključila strukturirane intervjue s predstavnicima vodstva 11 visokih učilišta. Istraživanja su pokazala da, iako većina hrvatskih visokih učilišta ima implementirane strategije $i$ planove za unaprjeđenje

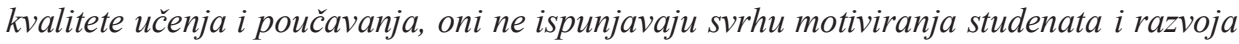
praksi učenja i poučavanja. U ovom radu su integrirani različiti pristupi analizi kvalitete učenja i poučavanja. Sveobuhvatan okvir za istraživanje kvalitete učenja i poučavanja uključio je strateški menadžment, inovacije i upravljanje kvalitetom. Posebno se ističe značaj inovativnih praksi za razvoj kvalitete učenja i poučavanja te se predlažu smjernice za vodstvo visokih učilišta kako bi se unaprijedila kvaliteta učenja i poučavanja.

Ključne riječi: kvaliteta usluge, inovacije, unaprjeđenje kvalitete, visoko obrazovanje, Hrvatska.

JEL klasifikacija: $123, O$

4 Doc.dr.sc. Ines Dužević, Ekonomski fakultet, Sveučilište u Zagrebu, Katedra za trgovinu i međunarodno poslovanje, Zagreb, Hrvatska, E-mail: iduzevic@efzg.hr *dopisni autor

${ }^{5}$ Izv.prof.dr.sc. Tomislav Baković, Ekonomski fakultet, Sveučilište u Zagrebu, Katedra za trgovinu i međunarodno poslovanje, Zagreb, Hrvatska, E-mail: tbakovic@efzg.hr

${ }^{6}$ Dr.sc. Mia Delić, poslijedoktorand, Ekonomski fakultet, Sveučilište u Zagrebu, Katedra za trgovinu i međunarodno poslovanje, Zagreb, Hrvatska, mdelic@efzg.hr 